\title{
Photovoltaic Cells and Systems: Current State and Future Trends
}

\author{
Hadj Bourdoucen, Joseph A. Jervase, Abdullah Al-Badi, Adel Gastli \\ and Arif Malik
}

Department of Electrical \& Electronics Engineering, College of Engineering, Sultan Qaboos University, P. O. Box 33, Al Khod 123, Muscat, Sultanate of Oman.

\section{الظلايا ولأظظمة الثطسية ، الوضع الحالي والفةق المسقبلية}

\section{حاج بورنون وجوزف جرفيس و عبد ا البادي و عال الفمللي و عاف ماك}

\author{
خلاصدة : الفوطائية الضوئية هي عملية تحويل الطاقة للشمسية إلىطلئة كهربائية. أي ظلم فولاطئي ضضوئي \\ يتكون بشكل ثابت من مصفوفلت من الخلايا للشمسية ومحول الطالة الكهربائية.

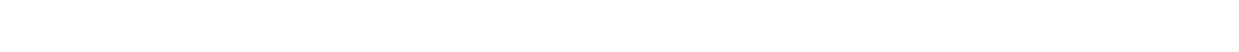

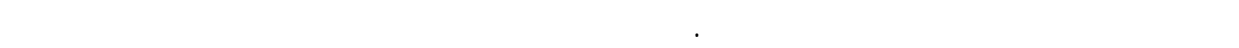

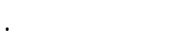

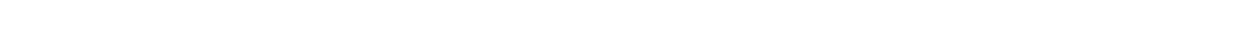

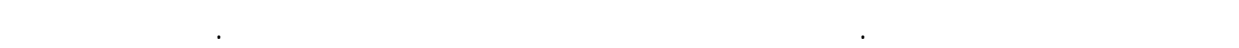 \\ خلاصة للمواد والتكنولوجيا الحالية والمسقبلية المستخمة في صناعة الخلايا للمنسية.
}

\begin{abstract}
Photovoltaics is the process of converting solar energy into electrical energy. Any photovoltaic system invariably consists of solar cell arrays and electric power conditioners. Photovoltaic systems are reliable, quiet, safe and both environmentally benign and self-sustaining. In addition, they are cost-effective for applications in remote areas. This paper presents a review of solar system components and integration, manufacturing, applications, and basic research related to photovoltaics. Photovoltaic applications in Oman are also presented. Finally, the existing and the future trends in technologies and materials used for the fabrication of solar cells are summarized.
\end{abstract}




\section{CONTENTS}

1. Introduction 186

2. PV Energy Conversion $r$

3. Solar Cells Material and Technologies $\quad 193$

3.1 Amorphous Silicon Cells $\quad 194$

3.2 Polysilicon Thin Films 194

3.3 Transparent Conductors $\quad 195$

3.4 Gallium Arsenide and other Semiconductor Compounds $\quad 195$

$\begin{array}{ll}3.5 \text { Cadmium Telluride } & 195\end{array}$

3.6 Copper Indium Diselenide (and related alloys) 195

3.7 Film Silicon and Dye-Sensitized Titanium Dioxide Cells 196

4. PV Systems 196

4.1 Solar Modules $\quad 197$

$\begin{array}{ll}4.2 \text { Energy Storage } & 197\end{array}$

$\begin{array}{lr}4.3 \text { Backup Systems } & 198\end{array}$

$\begin{array}{lr}4.4 \text { Power conditioning } & 198\end{array}$

5. Applications $r$

6. PV in Oman $r$

\begin{tabular}{lr} 
7. Future Trends & 201 \\
\hline 8. Conclusion
\end{tabular}

\begin{tabular}{lr} 
8. Conclusion & 203 \\
\hline . References & 203
\end{tabular}

9. References $\quad 203$

\section{Introduction}

Dhotovoltaic (PV) solar cells were originally developed for use in space, where repair is extremely expensive, if not impossible. Since the PV cells use the energy from sunlight to produce electricity, the fuel is free. Because of the low-maintenance, cost-effective PV systems are ideal for supplying power to communication stations on mountain tops, navigational buoys at sea, remote homes and villages, water pumping, and hybrid utility power substations. Once installed, PV power systems can operate continuously with little upkeep and minimal operating costs. Since they burn no fuel and have no moving parts, PV systems are clean and silent. This is especially important where the main alternatives for obtaining power and light are from diesel generators and kerosene lanterns. As we begin to realize and respect the fragility of our planet's ecosystem, clean power choices like PV become extremely important. According to different studies, the amount of energy available to generate photovoltaic power is almost 10,000 times greater than the total world energy used today. To harness this huge potential energy source, much research work has been done in this area (Moskowitz 1987, San Martin 1989, Moskowitz et al 1990a, Moskowitz et al 1990b, NREL 1996, Sayigh 1998). Also, the disruption of oil supplies in the early 1970s pushed the industrialized countries to seriously consider the photovoltaic options as a potential source of energy for terrestrial uses. This application focused research attention on improving performance, lowering costs and increasing reliability. These three issues remain important today even though researchers have made extraordinary progress over the years.

It is interesting to note that very soon after Heinrich Hertz realized the first cells using selenium, in the $1870 \mathrm{~s}$, this material has been rapidly used for PV cells converting light into electricity at $1 \%$ to $2 \%$ efficiency. As a result, selenium was quickly adopted in the emerging field of photography for use in lightmeasuring devices. Major steps toward commercializing PV were taken in the 1940s and early 1950s, when the Czochralski process was developed for producing highly pure crystalline silicon (Pierret 1996). Note that large single crystals of device-grade silicon used for solar cells are commonly produced using this crystal growth method. In 1954, scientists at Bell Laboratories depended on the Czochralski process to develop the first crystalline silicon photovoltaic cell, which had an efficiency of 4\% (Chalin et al 1954, 


\section{PHOTOVOLTAIC CELLS AND SYSTEMS}

Green et al 1999). The rapid evolution of silicon technology in the 1950's saw parallel evolution in silicon cell technology such that cells of close to $15 \%$ energy conversion efficiency had been demonstrated by the 1960 's. Standardization of cell design for space application seems to have inhibited innovation for about a decade, with the next burst of activity occurring in the early 1970's. This arose from incorporating technological improvements developed in the microelectronics area. This includes photolithography, cell design improvements such as texturing of the cell surfaces, and rear contact passivation using alloyed aluminum layers. By the mid-1970's, cells of terrestrial efficiency of close to $17 \%$ had been demonstrated.

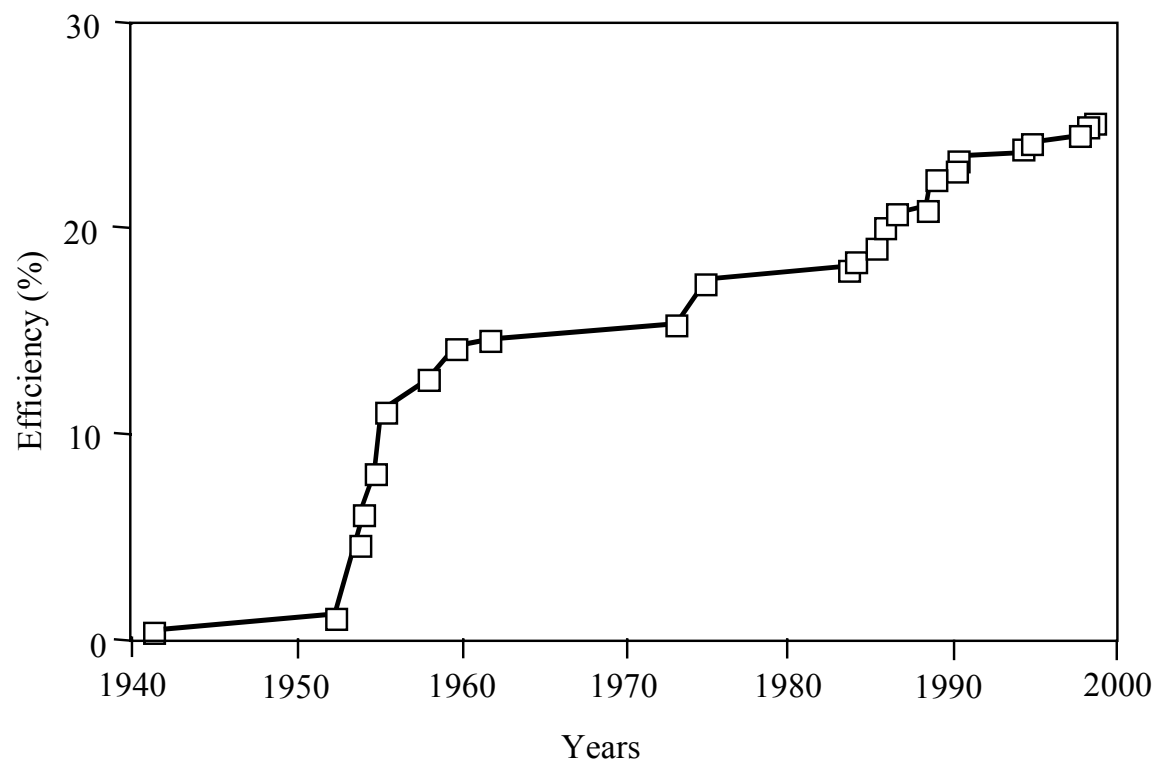

Figure 1. Evolution of laboratory silicon solar cell efficiency

It is apparent from figure 1 that improvements in performance have come sometimes in "steps" and sometimes in "surges." Each of these steps usually corresponds to a new technological or design feature, which is steadily exploited over a period generally lasting over a year or so. Silicon by itself is used in more than $90 \%$ of the commercial solar cells in different PV systems (Wiesman et al 1979, Matsumura 1986, ORE (US) 1989, Meyers 1990, Kapur and Basol 1990, Zweibel and Mitchell 1990, Brown 1991, Wagner and Carlson 1991, Tolley and Palmer, 1991, Zweibel and Chu 1993, Luft and Von Roedern 1994, Green et al 1999). Figure 2 shows the world PV cell and modules shipments from 1988 to 1995.

This review starts with a section on photovoltaic systems in which photovoltaic conversion principles, materials, manufacturing processes and current market place are discussed. Description of some typical applications and uses of PV energy are presented in the subsequent section. PV specifications relevant to Oman and the future trends for this technology are discussed in the following sections. Conclusions drawn from this review are embodied in the last section.

\section{PV Energy Conversion Process}

To understand the many facets of photovoltaic power, one must understand the fundamentals of how the device works. Although photovoltaic cells come in a variety of forms, the most common structure is a semiconductor material into which a large-area diode, mostly $\mathrm{p}-\mathrm{n}$ junction, has been formed. Figure 3 is schematic depiction of a rudimentary solar cell that shows its important features. A typical p-n 
junction solar cell consists of a shallow p-n junction formed at the front collection side, a front metallic contact stripe fingers, aback ohmic contact that covers the entire back surface, and an antireflection coating on the front surface. Electrical current is taken from the device through a grid contact structure on the front that allows the sunlight to enter the solar cell. A contact on the back that completes the circuit and an antireflection coating that minimizes the amount of sunlight reflecting from the device is placed on top of it. The fabrication of the p-n junction is a key to successful operation of the photovoltaic device as well as other important III-V and II-IV compound semiconductor photovoltaic devices.

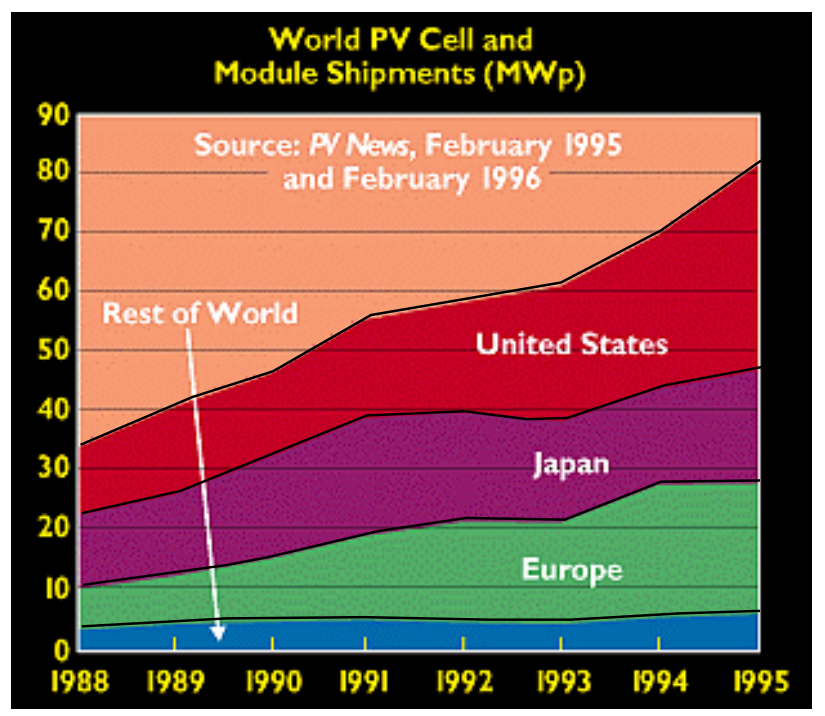

Figure 2. World PV cell and modules shipment

More advanced high efficiency solar cells are shown in figures 4 and 5 . Figure 4 for instance, is a schematic representation of what was known as the COMSAT nonreflecting cell first demonstrated in 1974 (Green et al 1999). The cell incorporated a textured surface formed by an isotropically etching of a silicon wafer to expose slowly etching, intersecting equivalent planes to form the square based pyramids shown. The junction was formed in the top surface by reasonably shallow phosphorus diffusion (Junction depth about $0.25 \mu \mathrm{m}$ ). The rear surface often had aluminum evaporated and alloyed to form a heavily doped region along the rear surface, somewhat inappropriately known as a "back surface field." Metallization was accomplished using photolithographic techniques for the front surface and consisted of a titanium/palladium/silver tri-metal layer with the same trilayer deposited over the entire rear surface. Titanium or tantalum oxides were preferred choices for the antireflection coating. These cells demonstrated efficiency under Air Mass zero (AM0) ${ }^{1}$ radiation of $15.0-15.5 \%$, which would correspond to efficiencies under the present global Air Mass 1.5 terrestrial standard of 16.7-17.2\%. The Air Mass parameter $m$, is dependent on the angle of incidence $\alpha\left({ }^{\circ}\right)$, the pressure $\mathrm{P}$ (millibars) and the path length through the atmosphere $z(\mathrm{~km})$. It is given by $m=(\exp (-z / 7.8) / \cos \alpha)(P / 1013)$, where the different variables are shown in figure 6.

\footnotetext{
${ }^{1} \mathrm{AM} 0$ is the power level of the solar spectrum in outer space, which is about $1.4 \mathrm{~kW} / \mathrm{m}^{2}$. On the earth at sea level, with the sun at zenith, the power level is nearly $1 \mathrm{~kW} / \mathrm{m}^{2}$, which is the AM1 spectrum.
} 

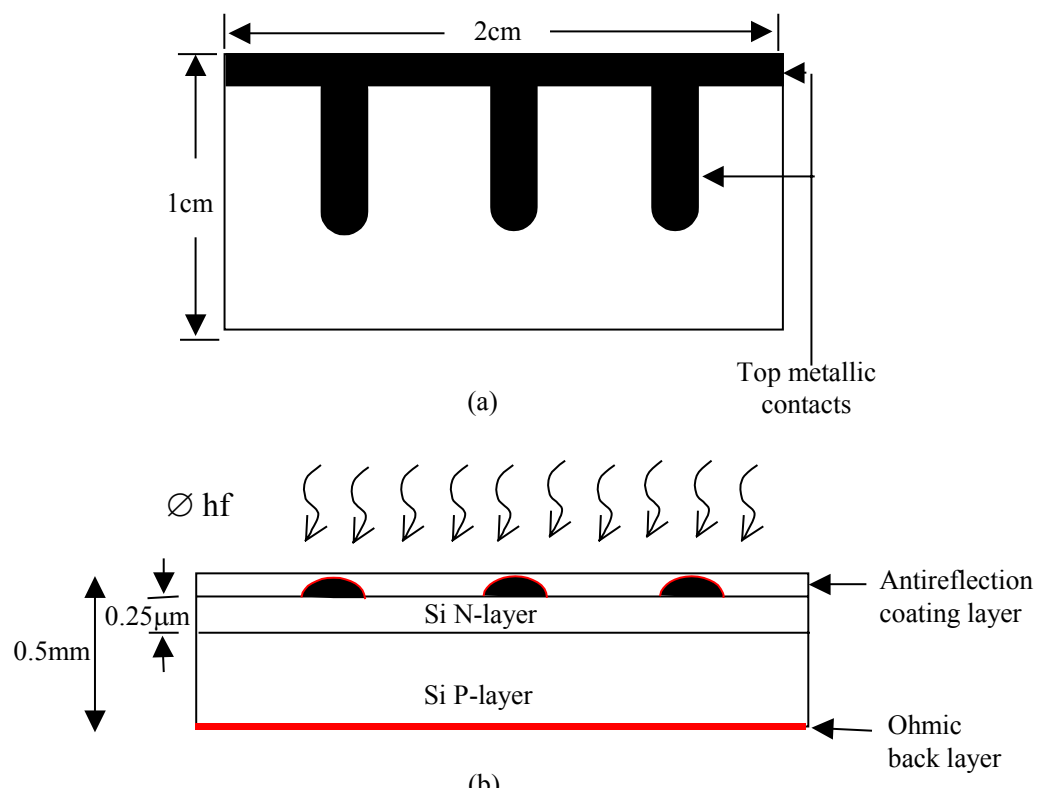

(b)
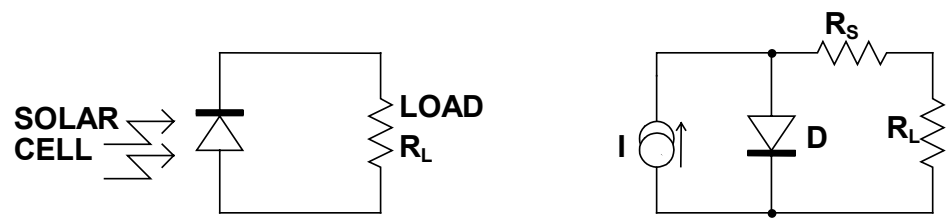

(c)

Figure 3. Schematic representation of a silicon solar cell and a simplified electric equivalent circuit for a solar cell

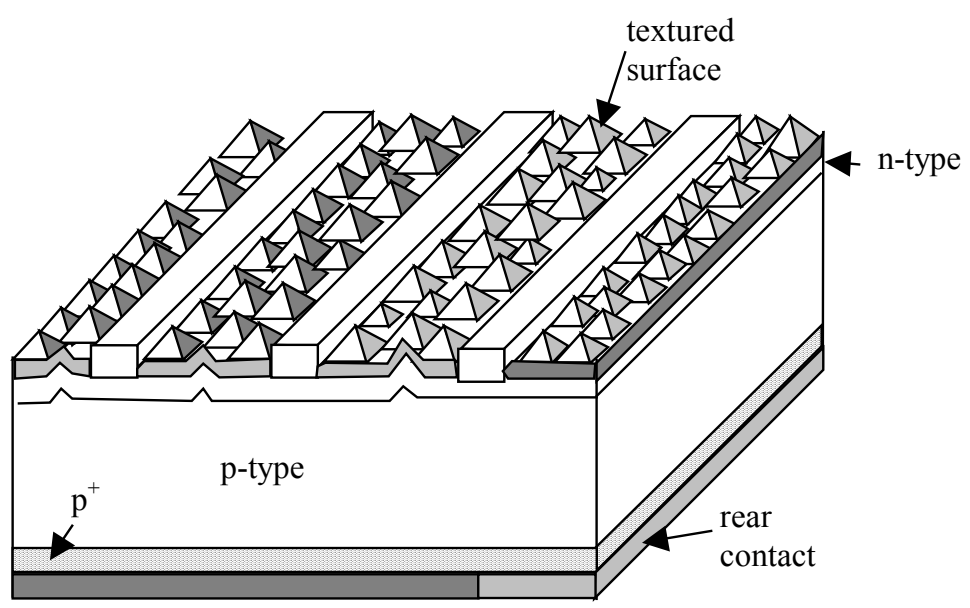

Figure 4. COSMAT non-reflecting cell (black cell) 


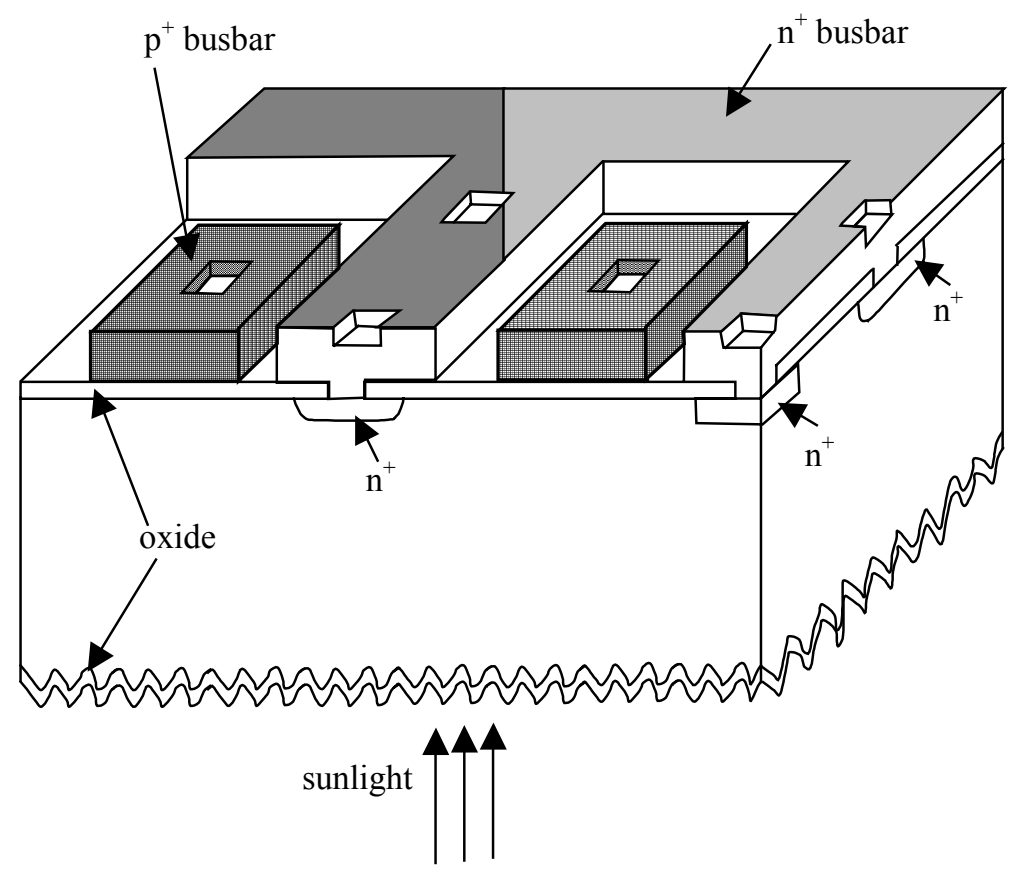

Figure 5. Rear point contact solar cell.

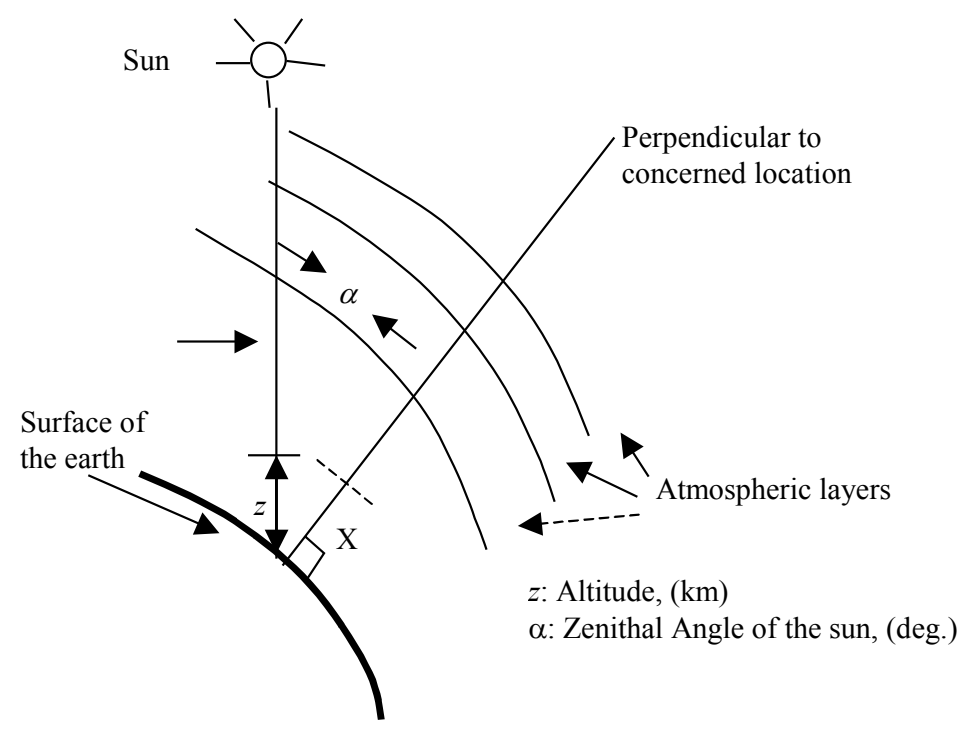

Figure 6. Representation of solar illumination on the earth's surface 


\section{PHOTOVOLTAIC CELLS AND SYSTEMS}

When the solar cell is exposed to an optical radiation (solar in this case), the photons with energy higher than the energy gap $E_{g}$ of the material used in the fabrication of the p-n junction cell will be absorbed and contribute to the generation of electron-hole pairs. The remaining absorbed energy is lost in the form of heat. With reference to figure 3 , if $I$ is the current through an illuminated solar cell, $V_{D}$ the voltage across it and $I_{L}$ is the current through a given connected load $R_{L}$, then

$$
I=I_{S}\left[\exp \left(q V_{D} / k T\right)-1\right]-I_{L}
$$

In equation (1), $I$ stands for the photogenerated current, $I_{S}$ is the reverse saturation current, $q$ is the fundamental electronic charge of $1.602 \times 10^{-19}$ coulombs, $k$ is the Boltzmann constant, and $T$ is the absolute temperature.

The saturation current density $J_{S}$ is expressed in terms of the physical parameters of the material as

$$
J_{S}=\frac{I_{S}}{A}=q N_{C} N_{V}\left[\frac{1}{N_{A}} \sqrt{\frac{D_{n}}{\tau_{n}}}\right]+\left[\frac{1}{N_{D}} \sqrt{\frac{D_{p}}{\tau_{p}}}\right] \exp \left(-E_{g} / k T\right)
$$

where, $A$ is the cell area, $N_{A}$ and $N_{D}$ are the doping densities of acceptors and donors respectively, $D_{n}$ and $D_{p}, \tau_{n}$ and $\tau_{p}$ are respectively the diffusion constants and the carriers lifetimes for electrons and holes. From equation (2), $J_{S}$ depends exponentially on the temperature of the junction and hence, the total current through the cell is highly dependent on $T . J_{S}$ is larger for materials with smaller bandgaps than for those with larger bandgaps $E_{g}$. On the other hand, the rectifier action of a cell, i.e. its restriction of current flow to only one direction, is key to the operation of the photovoltaic device.

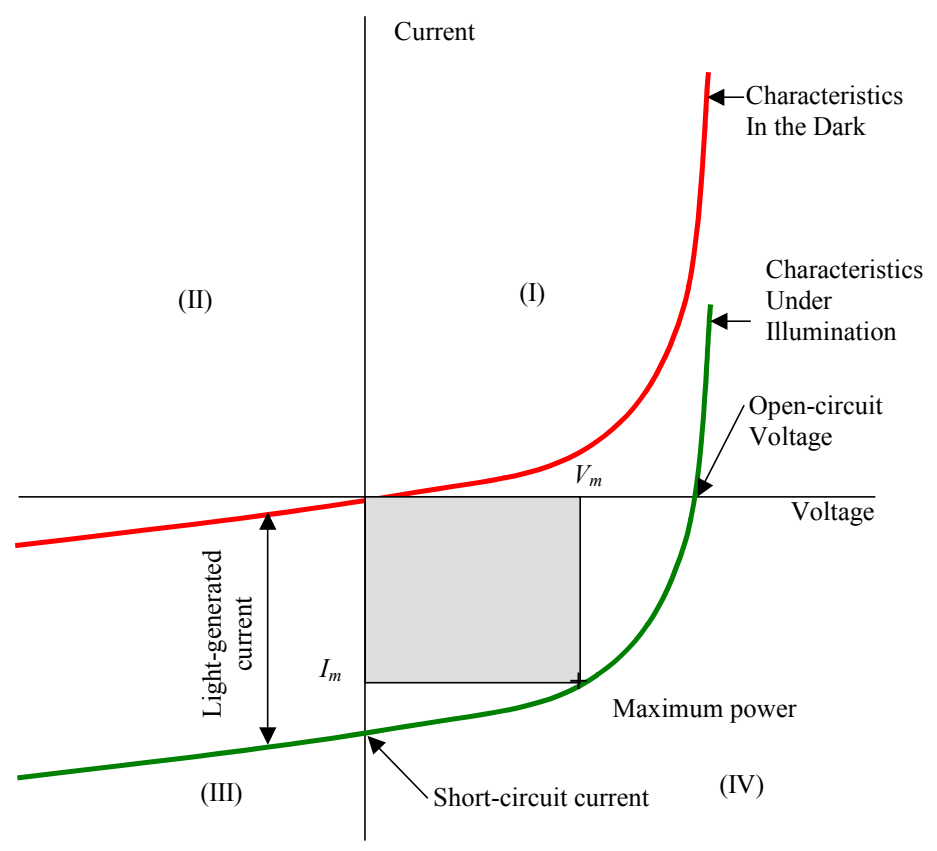

Figure 7. Current voltage characteristics of a solar cell with and without illumination 
From the operating point of view, when light is allowed to impinge on a $p$-n junction device, the equilibrium conditions of the device are disturbed. Minority carriers (electrons in the p material and holes in the $n$ material) are created in sufficient quantities to lower the potential energy barrier at the junction, allowing current to flow and establish a voltage at the external terminals. The availability of current and voltage produces usable power.

A current-voltage diagram, like the one in figure 7, shows the important operational parameters of the cell, among which is the short-circuit current $I_{s c}$, the open-circuit voltage $V_{o c}$, and the maximum power operating point ( $I_{m}$ and $V_{m}$, respectively).

The open circuit voltage $V_{o c}$ defined at $I=0$ is given by

$$
V_{O C} \cong \frac{k T}{q} \ln \left[\frac{I_{L}}{I_{S}}\right]
$$

The I-V curve gives the output power of the solar cell, which can be expressed as

$$
P=V I=I_{S} V(\exp (q V / k T)-1)-I_{L} V
$$

The maximum power output occurs when the derivative of the power vanishes. If $R_{S}$ is neglected, the expressions for $I_{m}$ and $V_{m}$ are given as

$$
V_{m}=\frac{k T}{q} \ln \left[\frac{1+\left(I_{L} / I_{S}\right)}{1+\left(q V_{m} / k T\right)}\right] \approx V_{O C}-\frac{k T}{q} \ln \left[1+\left(q V_{m} / k T\right)\right]
$$

and

$$
I_{m}=I_{S}\left[\frac{q V_{m}}{k T}\right] \exp \left(q V_{m} / k T\right) \approx I_{L}\left[1-\frac{1}{q V_{m} / k T}\right]
$$

The maximum output power $P_{m}$ is thus,

$$
P_{m}=I_{m} V_{m} \approx I_{L}\left[V_{o c}-\frac{k T}{q} \ln \left(1+\frac{q V_{m}}{k T}\right)-\frac{k T}{q}\right]
$$

The conversion efficiency of a solar cell, which is the ratio of the maximum power that a solar cell can deliver $\left(I_{m}, V_{m}\right)$ to the total incident power $P_{i n}$, can be expressed as (Sze, 1981).

$$
\eta=\frac{I_{m} V_{m}}{P_{i n}}=\frac{I_{L}\left[V_{o c}-\frac{k T}{q} \ln \left(1+\frac{q V_{m}}{k T}\right)-\frac{k T}{q}\right]}{P_{i n}}
$$

This can be expressed in terms of the fill factor $F F$ as

$$
\eta=\frac{F F \cdot I_{L} \cdot V_{o c}}{P_{i n}}
$$


where the fill factor $F F$ is defined as

$$
F F=V_{m} I_{m} / V_{o c} I_{s c}
$$

The fill factor ranges from approximately 0.70 to 0.85 . For a typical single-crystal silicon solar cell, we find that $V_{o c} \approx 0.588 \mathrm{~V}, J_{s c} \approx 35 \mathrm{~mA} / \mathrm{cm}^{2}$ and $F F \approx 0.8$. Thus a $100 \mathrm{~cm}^{2}$ cell is capable of producing about 1.6 watts (Sze 1985).

In the previous analysis the series resistance $R_{S}$ has been neglected, however, this resistance due to the front ohmic resistance is a major factor in degrading the efficiency of the solar cell. The output current $I$ and the output power $P$ can be rewritten as functions of $R_{S}$, as follows:

$$
\begin{gathered}
I=I_{S} \times\left\{\exp \left[\frac{q\left(V-I R_{S}\right)}{k T}\right]-1\right\}-I_{L} \\
P=I \times\left\{\frac{k T}{q} \ln \left[\frac{I+I_{L}}{I_{S}}+1\right]+I R_{S}\right\}
\end{gathered}
$$

It is important to note that a series resistance of only 4 to $5 \mathrm{ohms}$ can reduce the available power of a given cell by more than $70 \%$. This series resistance depends on both the architecture and the fabrication technology used. In particular, it depends on the junction depth, the impurity concentration of both acceptors and donors, and the type of front and back ohmic contacts. For a typical solar cell having an area of $2 \mathrm{~cm}^{2}, 0.25 \mu \mathrm{m}$ junction depth, substrate of $0.5 \mathrm{~mm}$ with $1 \Omega-\mathrm{cm}$ resistivity, the series resistance is of the order of $0.7 \Omega$.

\section{Solar Cells Materials and Technologies}

There are a number of new major developments including GaInP tandem solar cells for space, the mergence of thin films of crystalline silicon, and thermophotovoltaics. A thorough presentation of the recent advances and future trends of these technologies are presented in (Barnett et al 1999, Wohlgemuth et al 1991, Izu 1992, Stanbery 1991, Brown 1991).

Crystalline silicon solar cells are exhibiting improved and reduced cost, and continue to dominate world PV production, constituting in 1997 about 85\% of the PV-market share. The crystalline market is subdivided into single or mono-crystalline and multicrystalline silicon cells and a small market share for ribbons. The major problem of relatively thick bulk crystalline silicon solar cells is availability of good quality silicon feedstock material. Initiatives for starting a dedicated low-cost solar grade multicrystalline silicon production are still in pilot line phase (Maurits 1998). However, thin-film solar cells of amorphous silicon-hydrogen, copper indium diselenide (CuInSe), and cadmium telluride (CdTe) have begun to be sold for power applications (Barnett et al 1999).

A very crucial step in the fabrication of crystalline silicon solar cells is ingot formation for which two competing technologies are available. These are the Czochralski pulling of monocrystalline ingots and the casting process of multicrystalline silicon ingots. Monocrystalline silicon has several important advantages for solar cell processing (Nijs et al 1969, Schmidt et al 1997, Kaneko et al 1997, Watanabe et al 1990). The apparent advantages of multicrystalline silicon, in general, over monocrystalline are a lower wafer cost and perfect long-term cell stability. Solar cell efficiencies approaching those of monocrystalline cells are obtained in a more complicated process, comprising deposition of antireflection coating and hydrogen bulk passivation. In terms of dimensions, the standard substrate size $10.16 \times 12.16 \mathrm{~cm}^{2}\left(4 \times 4 \mathrm{in}^{2}\right)$ has been adopted for long time; however, there is recently a clear tendency toward larger sizes. Most of the solar cell manufacturers base their production lines on $12.7 \times 12.7 \mathrm{~cm}^{2}\left(5 \times 5 \mathrm{in}^{2}\right)$ wafers. Efficient cells processed on $15.24 \times 15.24 \mathrm{~cm}^{2}\left(6 \times 6 \mathrm{in}^{2}\right)$ and even $19.81 \times 19.81 \mathrm{~cm}^{2}\left(7.8 \times 7.8 \mathrm{in}^{2}\right)$ substrates have been reported (Kaneko et al 1997). The driving force toward these larger cell sizes results from the fact that cell manufacturing and 
module assembly costs show relatively small area dependence, and therefore, the cost to power ratio decreases with increasing cell size. On the other hand, the cell size is limited by its series resistance; as indicated previously, and also by limitations of module sizes due to handling, wind loads, module transportation, and system assembly (Nijs et al 1969, Villers and Smekens 1995).

Due to the success of developments in multi-wire sawing, a wafer thickness of $150 \mu \mathrm{m}$ or smaller is becoming feasible, corresponding to final cell thickness of $120 \mu \mathrm{m}$ or lower (Villers and Smekens 1995). This allows an important saving of silicon material. At the same time, thinner cells correspond better to the optimum thickness if efficient light trapping and surface passivation are possible (Munzer et al 1998). In spite of significant progress in slicing techniques, there is still around $200 \mu \mathrm{m}$ of high-quality silicon per wafer lost in kerfs waste. Limitations to further decrease the final wafer thickness are set by a decrease in yield due to handling problems and breakage during solar cell and module fabrication. To produce silicon directly in sheet forms, and so to avoid the costs of wafering and kerfs losses, the ribbons technology is widely used. A number of ribbon techniques have been developed and used in solar cell applications with each technique having its own advantages and disadvantages. The Dendritic Web technology, for instance, is one of the very few techniques that yield ribbons in single crystalline form. However, the edge-defined film-fed growth (EFG) ribbon process is a technology that was initially developed in the 1970's and had been steadily progressing into multiple silicon ribbon growth of large area sheets in the form of tubes (Mackintosh et al 1978, Taylor et al 1981, Kalejs et al 1994, Sana et al 1993). Laboratory conversion efficiencies of about $14 \%$ have been reached with this technology.

The String ribbon process, on the other hand, was initially developed as "edge supported ribbon" (Cizek et al 1981, Janoch et al 1997, Wallace et al 1997), and is presently improved and commercialized. When two strings of a high-temperature material are brought up through the silicon melt, a continuous silicon film is drawn from the melt after seeding silicon. The resulting film after solidification is polycrystalline. The silicon sheets from powder technique (SSP) consists of using silicon in a powder form as the starting material. It is poured through a funnel into quartz carrier sheets (Eyer et al 1989) which, first travel into a "first melting zone" where surface melting of the powder layer is achieved by a focused lampbank. Laboratory scale conversion efficiencies of $13.2 \%$ were reported for $4 \mathrm{~cm}^{2}$ cells. Cells fabricated with a relatively faster modified technique achieved a laboratory efficiency of $8 \%$ on $4 \mathrm{~cm}^{2}$ cells (Faller 1997).

Finally the so-called ribbon growth on substrates (RGS) process is a horizontal ribbon growth technology where a substrate is used for the cooling over the bottom surface of the ribbon. The heat is removed by conduction, perpendicularly to the pulling direction, over the ribbon surface. The crystallization and pulling velocities are therefore decoupled, leading to high production rate (Steinbach and Hofs 1997, Hahn et al 1997A). Efficiencies of the order of 11\% have been recently reported (Hahn et al 1997B).

\subsection{Amorphous Silicon Cells}

Amorphous solids, like common glass, are materials in which the atoms are not arranged in any particular order. They do not form crystalline structures at all, and they contain large numbers of structural and bonding defects. It wasn't until 1974 that researchers began to realize that amorphous silicon could be used in PV devices by properly controlling the conditions under which it was deposited and by carefully modifying its composition. Today, amorphous silicon is commonly used for solar-powered consumer devices that have low power requirements. Significant advances have been also made in understanding amorphous silicon alloy materials and solar cells that have resulted in the achievement of high cell and module efficiency. The research results have been also translated to production, and several manufacturers have expanded their production capacity, raising the worldwide annual capacity to more than $25 \mathrm{MW}$ (Guha and Yang 1999).

\subsection{Polysilicon Thin Films}

Polycrystalline thin-film devices require very little semiconductor material and have the added advantage of being easy to manufacture. Rather than growing, slicing, and treating a crystalline ingot 


\section{PHOTOVOLTAIC CELLS AND SYSTEMS}

(required for single-crystal silicon), thin layers of the required materials are sequentially deposited. Several different deposition techniques are available, and all of them are potentially cheaper than the ingot-growth techniques required for crystalline silicon (Meyers 1990). Best of all, these deposition processes can be scaled up easily so that the same technique used to make a $5.08 \times 5.08 \mathrm{~cm}(2 \times 2 \mathrm{in})$ laboratory cell can be used to make a $0.61 \times 1.52 \mathrm{~m}(2 \times 5 \mathrm{ft})$ module (Russell et al 1984).

\subsection{Transparent Conductors}

These are alternative materials for grid contacts, which are transparent conducting oxides (TCO) such as tin oxide $\left(\mathrm{SnO}_{2}\right)$. Their advantage is that they are transparent to incoming light and yet form a good electric contact linking the semiconductor with the external circuit.

\subsection{Gallium Arsenide and other Semiconductor Compounds}

Gallium arsenide (GaAs) is especially suitable for use in multijunction and high-efficiency solar cells for several reasons. Its energy band gap of $1.43 \mathrm{eV}$ makes it ideal for single-junction solar cells. Its optical absorption coefficient is high enough to require a cell of only a few microns thick to absorb most of the sunlight radiation. Unlike silicon cells, GaAs cells are relatively insensitive to heat within the limits of application temperatures. GaAs is also characterized by its very high resistance to radiation damage. This, along with its high efficiency, makes GaAs very desirable for space applications. The alloys made from GaAs using aluminum, phosphorus, antimony, or indium, have characteristics complementary to those of GaAs, allowing great flexibility in cell design. The greatest barrier to the widespread use of GaAs cells has been the high cost of the single-crystal substrate. They are mainly used in concentrator systems, where the typical concentrator cell is about $0.25 \mathrm{~cm}^{2}$ in area. In this case, the cost is low enough to make GaAs cells competitive, assuming that module efficiencies can reach between $25 \%$ and $30 \%$ and that the cost of the rest of the system can be reduced.

\subsection{Cadmium Telluride}

The thin-film technology next closest to commercialization is based on cadmium telluride. Its cell efficiencies are high, around $16 \%$ in the laboratory, but commercial module efficiencies are likely to be in the $6 \%$ to $8 \%$ range in the first plants. Considering the advantages of photovoltaics in offsetting other sources of energy, the cadmium telluride issue should be put in the same perspective as similar issues. Owing to the nature of 'thin film' CdTe modules, the use of cadmium in PV is always likely to remain a small fraction (under 10\%) of the world's use of cadmium even if CdTe modules are one day able to provide a significant fraction, over 10\% of the world's electricity (Moskowitz et al 1987, Zweibel and Mitchell 1990, Moskowitz, and Fthenakis 1990, Moskowitz et al 1990A, Moskowitz et al 1990B, Alsema and Van Engelenburg 1992, Moskowitz and Zweibel 1992). Cadmium telluride technology suffers from the likelihood that near-term commercialization will encounter classic start-up issues, it has a stability problem (although stability is good in some cases), and it must raise the efficiency of modules toward those attained by the best cells, which will require head-on solution of processing challenges associated with fabricating thin cadmium sulfide (CdS) in manufacturing. If these problems can be solved over the next 10 years, CdTe technology has a very good chance to achieve the long-term cost, performance and stability goals (Stone et al 1984, Moskowitz et al 1987, San Martin 1989, Moskowitz and Fthenakis 1990, Moskowitz et al 1990A, Moskowitz et al 1990B, Moskowitz et al 1990C, Tolley and Palmer 1991, Alsema and Van Engelenburg 1992, Moskowitz and Zweibel 1992, Zweibel and Chu 1993). Viewed from this standpoint, it could be regarded as the leading thin film.

\subsection{Copper Indium Diselenide (and related alloys)}

Copper indium diselenide ( $\mathrm{CuInSe}$ ) cells have reached almost $18 \%$ efficiency under standard test conditions. This means that the best CuInSe cell is approaching the best efficiency of a polycrystalline silicon cell. 


\subsection{Film Silicon and Dye-Sensitized Titanium Dioxide Cells}

Several groups have tried to combine the strong performance of crystalline silicon devices with the attractive economic advantages of thin-film manufacturing technology. Thicker silicon cells on ceramic or foil substrates have been relatively efficient with cells and modules efficiencies around $15 \%$ and $9 \%$ respectively. Thin cells, on the other hand, have not yet reached such high efficiencies but the future of thin films looks strong (ORE (US) 1989, Wohlgemuth et al 1991, Albright 1991, Stanbery 1991, Jester 1991, Brown 1991, Izu 1992). Despite serious obstacles, amorphous silicon has established itself as a viable competitor for wafer-based crystalline silicon devices. Meanwhile, the next generation of thin films, in particular CuInSe and $\mathrm{CdTe}$, show stronger technical performance and lower potential cost (Wohlgemuth et al 1991, Izu 1992).

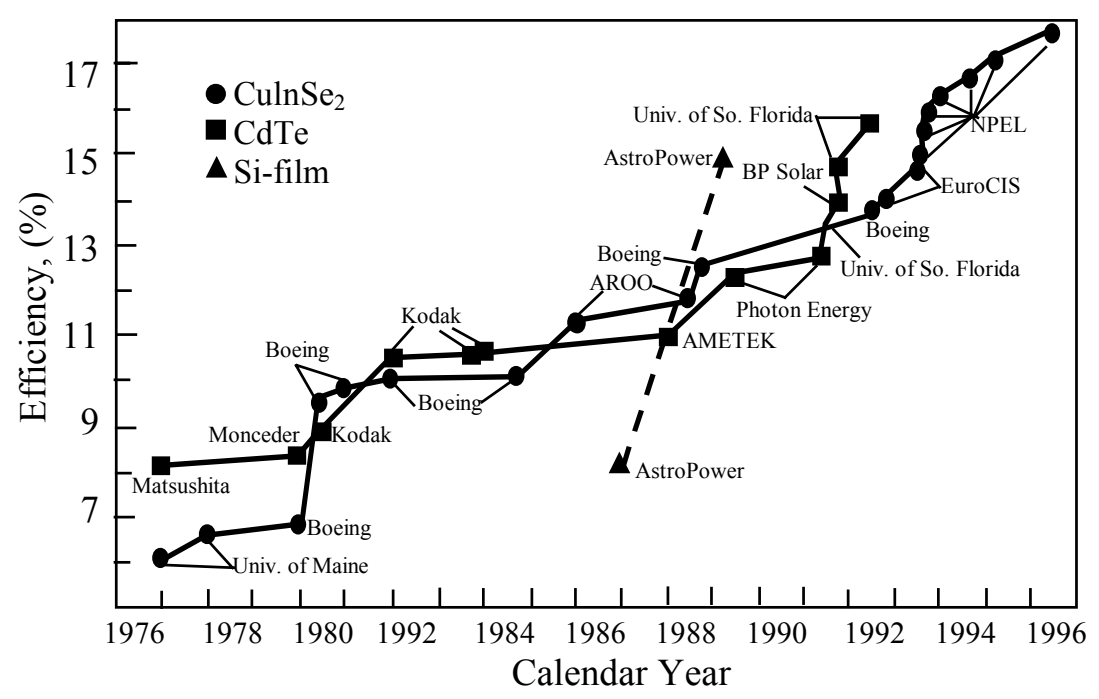

Figure 8. Polysilicon thin-film solar cell efficiencies.

In short, we can say that the driving force in search for and use of different materials and manufacturing processes to increase efficiency for PV cells is to reduce the overall cost to make it comparable with conventional technologies. For instance, the evolution of Si-film, CdTe and $\mathrm{CuInSe}_{2}$ thin film solar cell efficiencies are given in figure 8 for two decades. As can be seen from the figure, the general trend of the efficiencies for the above materials is increasing over the period, thus demonstrating the decrease in cost.

\section{PV Systems}

PV systems can be grouped into the following categories:

- Stand-alone systems with and without battery storage

- Systems with backup power generators

- Systems connected to a local utility

- Systems for utility-scale power production

- Hybrid power systems 


\section{PHOTOVOLTAIC CELLS AND SYSTEMS}

Table 1. Confirmed terrestrial cell and sub-module efficiencies measured under the global AM1.5 spectrum $\left(1000 \mathrm{Wm}^{-2}\right)$ at $25^{\circ} \mathrm{C}($ Green M. A. et al 1998$)$.

\begin{tabular}{|c|c|c|c|c|c|}
\hline Cell Types & $\begin{array}{l}\text { Efficiency } \\
\quad \eta(\%)\end{array}$ & $\begin{array}{l}\text { Area } \\
\text { A }\left(\mathrm{cm}^{2}\right)\end{array}$ & $\begin{array}{c}\text { Open Circuit } \\
{\text { Voltage } V_{\text {oc }}(V)}\end{array}$ & $\begin{array}{c}\text { Short circuit } \\
\text { current density } \\
\mathrm{J}_{\mathrm{sc}}\left(\mathrm{mA} / \mathrm{cm}^{2}\right)\end{array}$ & $\begin{array}{l}\text { Fill Factor } \\
\text { FF (\%) }\end{array}$ \\
\hline \multicolumn{6}{|l|}{ Silicon Cells } \\
\hline Si (crystalline) & $24.4 \pm 0.5$ & $4.00(\mathrm{da})$ & 0.696 & 42.0 & 83.6 \\
\hline Si (multicrystalline) & $19.8 \pm 0.5$ & 1.09 (ap) & 0.654 & 38.1 & 79.5 \\
\hline Si (supported film) & $16.6 \pm 0.5$ & 0.98 (ap) & 0.608 & 33.5 & 81.5 \\
\hline \multicolumn{6}{|l|}{ III-V Compounds } \\
\hline GaAs (crystalline cell) & $25.1 \pm 0.8$ & $3.91(\mathrm{t})$ & 1.022 & 28.2 & 87.1 \\
\hline GaAs (thin film cell) & 23.3 & 4.00 (ap) & 1.011 & 27.6 & 83.8 \\
\hline GaAs (multicrystalline) & $18.2 \pm 0.5$ & $4.011(\mathrm{t})$ & 0.994 & 23.0 & 79.7 \\
\hline InP (crystalline cell) & $21.9 \pm 0.7$ & $4.02(\mathrm{t})$ & 0.878 & 29.3 & 85.4 \\
\hline \multicolumn{6}{|l|}{$\begin{array}{c}\text { Polycrystalline Thin } \\
\text { Film }\end{array}$} \\
\hline CdTe (cell) & $16.0 \pm 0.2$ & 1.0 (ap) & 0.840 & 26.1 & 73.1 \\
\hline CdTe (submodule) & $10.6 \pm 0.3$ & 63.8(ap) & 6.565 & 2.26 & 71.4 \\
\hline \multicolumn{6}{|l|}{ Amorphous Silicon } \\
\hline a-Si (cell) & $12.7 \pm 0.4$ & $1.0(\mathrm{da})$ & 0.887 & 19.4 & 74.1 \\
\hline a-Si (submodule) & $12.0 \pm 0.4$ & 100 (ap) & 12.5 & 1.3 & 73.5 \\
\hline
\end{tabular}

$(\mathrm{ap})=$ aperture area; $(\mathrm{t})=$ total area; $(\mathrm{da})=$ designated illumination area.

Table 1 provides recent summary of the status of solar cells' efficiency, area, open circuit voltage, fill factor and current density for different materials used in current PV technologies (Green M. A. et al. 1998).

The main components of a typical PV system. These include solar modules, energy storage, power conditioning, and back up sub-systems. A discussion of some of the features of these components follows.

\subsection{Solar Modules}

The PV cell is the basic unit of a PV system. A typical single cell produces a power of 1 to 2 watts, hardly enough for most applications. However, the power can be increased by connecting many cells together to form a larger unit called module. Modules, in turn, can be connected to form arrays for more output electric power.

\subsection{Energy Storage}

In many PV systems, energy will not be used as it is produced but may be required at night or on cloudy days. If tapping into the utility grid is not an option, battery storage system will be necessary in most of the cases. Storing electrical energy makes PV systems a reliable source of electric power. PV systems with battery storage are being used all over the world to power lights, sensors, recording equipment, switches, appliances, telephones, televisions, and even power tools.

The drawbacks to batteries are that they decrease the efficiency of the PV system, because only about $80 \%$ of the energy channeled into them can be reclaimed. They also add to the expense of the overall 
system and must be replaced every five to ten years. They take up considerable floor space, pose some safety concerns, and require periodic maintenance.

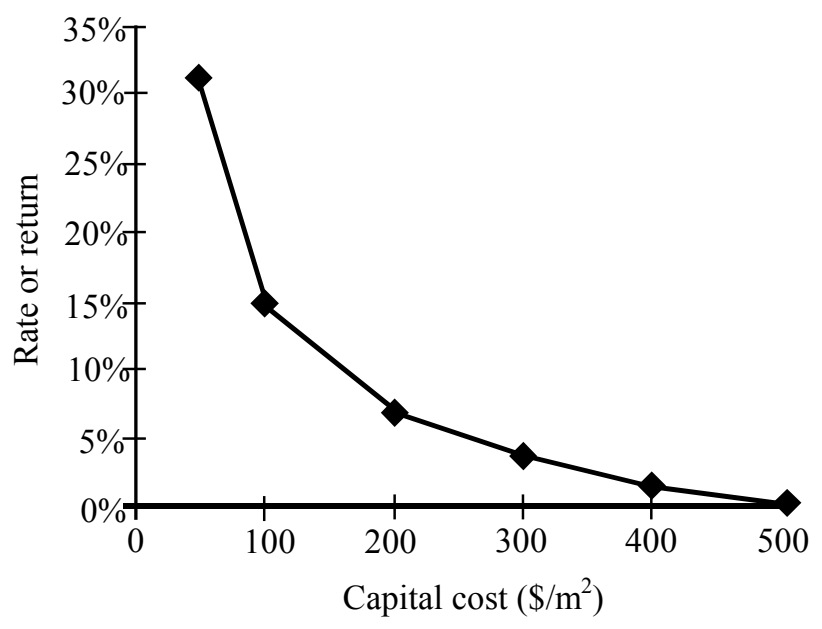

Figure 9. Layout of a wind-photovoltaic system.

Like PV cells, batteries are direct-current devices and are directly compatible only with dc loads. However, batteries can also serve as a power conditioner for these loads by regulating power; this allows the PV array to operate closer to its optimum power output. Most batteries must also be protected from overcharge and excessive discharge, which can cause electrolyte loss and can even damage or ruin the battery plates.

\subsection{Backup Systems}

When power must always be available or when larger amounts of electricity than a PV system alone can supply are occasionally needed, an electric generator can work effectively with a PV system to supply the load. During the daytime, the PV modules quietly supply daytime energy needs and charge batteries. If the batteries run low, the engine generator runs at full power-its most cost- and fuel-efficient mode of operation-until they are charged. And, in some systems, the generator makes up the difference when electrical demand exceeds the combined output of the PV modules and the batteries.

Systems using several types of electrical generation combine the advantages of each. Engine generators can provide an excellent backup for the PV modules. Using PV and generators together can also reduce the initial cost of the system. However, having an engine generator as backup means fewer PV modules and batteries are necessary to supply power whenever it is needed. Including generator makes designing PV systems more complex, but they are still easy to operate. In fact, modern electronic controllers allow such systems to operate automatically. Controllers can be set to automatically switch generators, to supply ac or dc loads, or do some of each. In addition to engine generators, electricity from wind generators, small hydro plants, and any other source of electrical energy can be added to make a larger hybrid power system.

\subsection{Power Conditioning}

PV systems usually require power conditioners to process the generated electric power to make it suitable for meeting the specific demands of the load. It is extremely important to match these devices to the load. Thus, power conditioners may have to perform a number of tasks. These include limiting current and 


\section{PHOTOVOLTAIC CELLS AND SYSTEMS}

voltage to maximize power output, converting dc power to ac power, matching the converted ac electricity to a utility electrical network, and safeguarding the utility network system and its personnel from possible harm during repairs.

The major concern in the design of dc-to-ac converters (inverters) is to minimize the losses of the converter energy conversion process. For instance, in 1996, solar plants with about $400 \mathrm{~kW}$ photovoltaic peak power were installed in Austria, producing approximately $360 \mathrm{MWh}$ (Edelmoser and Himmelstoss, 1999). An improvement of the total electrical efficiency of the inverters by only $1 \%$ would lead to an additional yield of 3.6MWh. The potential available in the whole world is therefore much higher.

Recently, new inverter concepts with increased efficiency were published (Oliveira and Maksimovic 1996, Mantovanelli and Barbi 1995, Solero et al 1996, and Midya et al 1996). Furthermore, cost reduction in new inverter concepts requires full digital control equipment using microcontrollers or signal processors (Makino et al 1995). Especially in grid-connected applications, a low-distortion inverter is required due to international standardization. This requires careful selection of the inverter structure, of the switching devices, and the control concept (Lai and Smedley 1995).

Edelmoser and Himmelstoss (1999) proposed a high efficiency dc-to-ac inverter for generating an ac mains (stand-alone system) or for grid connection. The new inverter leads to improved efficiency and is therefore well suited for solar and aerospace applications. Due to the minimum number of components, especially the active components, reliability is improved. Their proposed structure uses only off-line switches to generate the ac voltage. Due to safety reasons, the input voltage (e.g., the voltage of solar cells or batteries) is limited. Therefore, high currents on the primary side are necessary to obtain the required output power. The overall efficiency of the inverter depends to a high degree on the number of switching elements in the current path. Thus, the structure has only one active switch in the main path. This can be obtained by applying a diode with controlled turn-off capability (like a thyristor or other derivatives). High duty cycles of the main switch at high currents lead to low duty cycles of the switchable diode. For that reason, a series connection of two active switches in the main path has to be avoided. The improvement of the efficiency is due to the new topology and not due to over dimensioning of the semiconductors. Hence, an additional potential of efficiency improvement is still available.

\section{Applications}

Many people are familiar with PV-powered calculators and watches, the most common small-scale applications of PV cells. However, there are numerous large-scale, cost-effective PV applications, including:

- Water pumping for small-scale remote irrigation, stock watering, residential uses, remote villages, and marine sump pumps.

- Lighting for residential needs, billboards, security, highway signs, streets and parking lots, pathways, recreational vehicles, remote villages and schools, and marine navigational buoys.

- Communications by remote relay stations, emergency radios, orbiting satellites, and cellular telephones.

- Refrigeration for medical and recreational uses.

- Corrosion protection for pipelines and docks, petroleum and water wells, and underground tanks.

- Utility grids that produce utility or commercial-scale electricity.

- Household appliances such as ventilation fans, swamp coolers, televisions, blenders, stereos, and other appliances. 
Large-scale photovoltaic power plants, consisting of many PV arrays installed together, can prove useful to utilities. PV plants can be built much more quickly than conventional power plants because the arrays themselves are easy to install and connect together electrically. Finally, PV power plants consume no fuel and produce no air or water pollution while they silently generate electricity. For instance, a 2-MW photovoltaic power plant has been built in California to supply 660 houses (DEPP (US) 1998). However, PV generation plants have several limitations that have slowed their use by utilities. Under current utility accounting, PV-generated electricity still costs considerably more than electricity generated by conventional plants, and regulatory agencies require most utilities to supply electricity for the lowest cash cost. Furthermore, photovoltaic systems produce power only during daylight hours and their output varies with the weather. To get a general idea on the economic feasibility of a PV system, the curve in figure 9 can be used to estimate the rate of return on a capital outlay of a PV system.

In order to combine a number of electricity production and storage elements to meet the energy demand of a given facility or community, hybrid systems have been used. In addition to PV, engine generators, wind generators, small hydro plants, and any other source of electrical energy can be added as needed to meet energy demands and fit the local geographical and temporal characteristics. There are thousands of these systems in use worldwide. They range from a few tens of watts to tens of kilowatts. The smaller systems are mostly on remote residences where homeowners add a few PV modules to their existing generator set to reduce the noise and inconvenience of having a generator running all the time. Convenience may be more important than cost for these homeowner-maintained systems that are installed near their homes.

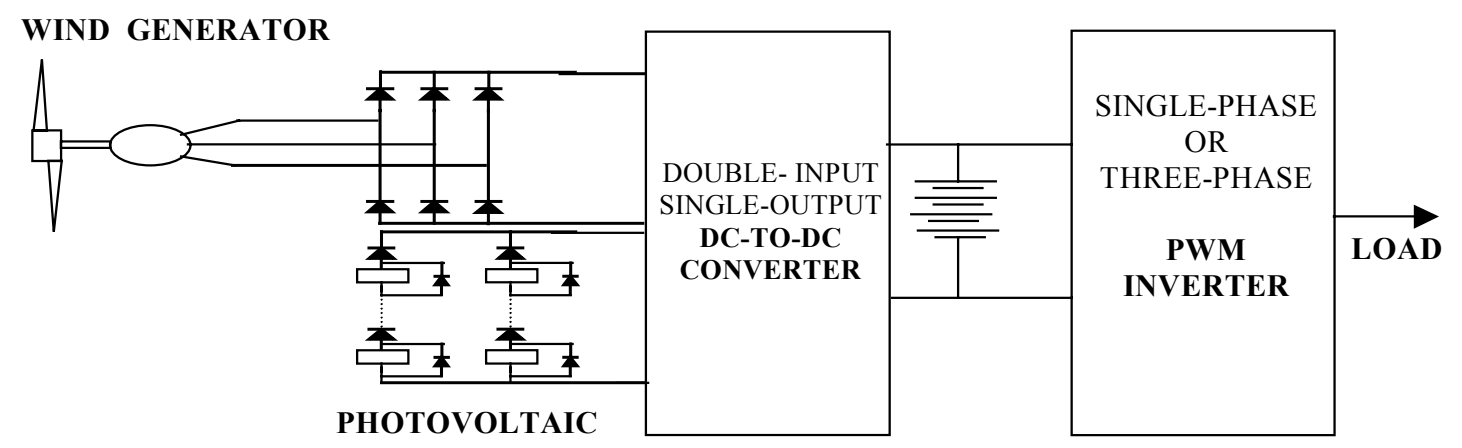

Figure 10. Rate of return as a function of capital cost for PV systems.

A $10 \mathrm{~kW}$ stand-alone wind/photovoltaic generating system prototype has been constructed (Caricchi et al 1993, Chalmers et al 1996, Crescimbini et al 1996). Figure 10 shows the layout of a system, which uses a wind turbine-driven permanent-magnet machine and a photovoltaic array as power generating units. The principal features of the system are, the double-input, single-output, d.c. to d.c. converter that combines the power generated by the wind and photovoltaic array and the d.c. to d.c. converter for charging a storage battery and supplying a.c. via a voltage source inverter.

The decreasing cost of PV systems and the increasing number of manufacturers and dealers for PV equipment have contributed to widespread use of the PV technology. In PV's early days, do-it-yourself had to search for companies that manufactured PV modules and often had to adapt or reconfigure components from other non-PV systems. Today, dealers offer ready-to-use systems and state-of-the-art equipment designed specially for PV systems. Many dealers have computer programs to design systems and specify appropriate components. As PV market expands, manufacturers and dealers are gaining greater experience with PV application and so making PV systems cheaper and easier to acquire. 


\section{PHOTOVOLTAIC CELLS AND SYSTEMS}

\section{6. $P V$ in Oman}

Oman national electricity grid does not cover all regions because of its topography, which makes its implementation quite expensive. So, for some of the isolated regions, PV systems are undoubtedly economically viable. Furthermore, PV electricity generation tends to be more cost effective in the "sun belt" region from about $40^{\circ}$ North to $40^{\circ}$ South, within which Oman lies (Al-Ismaily et al, 1998). Oman, with an average solar radiation of around $5.67 \mathrm{kWh} / \mathrm{m}^{2} /$ day (Al-Malki et al 1998), is very well suited for solar powered photovoltaic applications. This is due to the fact that sunshine availability and global insolation level have a major effect on the photovoltaic array size, as the current generated by the PV modules is directly proportional to the insolation level and sunshine duration. The more the sunshine duration, the lesser will be the PV array size. This is in fact the prevailing situation in Oman where the average sunshine duration is 9.49 hours with much less seasonal variation (Dorvlo and Ampratwum, 1998, Al-Hinai and AlAlawi 1998). Hence, this value of average sunshine availability may be taken for typical PV system sizing. However, if the sizing is critical, the regional sunshine or radiation availability data in Oman may be used (Dorvlo and Ampratwum 1998, Al-Alawi and Al-Hinai 1998, Al-Hinai and Al-Alawi 1998). Typical daily summary statistics data measured by Oman Department of Meteorology for four weather stations at different locations (Seeb, Sohar and Buraimi) are shown in Table 2.

Table 2. Daily summary statistics data of sunshine duration and mean solar radiation for some selected cities of Oman.

\begin{tabular}{|c|c|c|}
\hline Station & $\begin{array}{c}\text { Mean of sunshine } \\
\text { Hours }\end{array}$ & $\begin{array}{c}\text { Mean of solar radiation } \\
\left(\mathrm{MJ} / \mathrm{m}^{2} / \text { day }\right)\end{array}$ \\
\hline Seeb & 9.59 & 19.48 \\
\hline Sohar & 9.10 & $\overline{19.30}$ \\
\hline Buraimi & 10.24 & 16.22 \\
\hline Salallah & 7.88 & \\
\hline
\end{tabular}

Various successful implementations of the PV technology are already in use in Oman such as desalination plant in Heelat Ar Rakah camp (Al-Malki et al 1998). In 1991, Oman Solar Systems (OSS) Company was set up to supply the local market. The company has undertaken projects ranging from street and traffic lighting to microwave and television transmitter stations (Al-Ismaily et al, 1998).

\section{Future Trends}

The significant advances made during recent years are due to ongoing research in industry, universities and research laboratories. The current research work is focused on developing new materials, improving the efficiency and raising the power to cost ratio.

Thin films for instance, are a promising path to low-cost photovoltaic systems. For thin-film products to reach their low-cost potential, additional research is needed to develop materials and processes yielding devices with higher efficiencies, more uniform performance over the entire surface area of modules, and lower production costs (Schropp and Rath 1999, Yamamoto 1999). University researchers, and scientists are collaborating worldwide to develop prototype products largely based on amorphous silicon, cadmium telluride, copper indium diselenide, and thin-layer crystalline silicon technologies. Although amorphous silicon materials have lower efficiencies than does crystalline silicon, they have the potential to be less expensive to manufacture. Today, more than $15 \%$ of cells and modules produced worldwide are amorphous silicon. Most products using amorphous silicon are low-power consumer items like solar watches and 
calculators. Higher-power applications will demand amorphous silicon products with higher stabilized efficiencies so that more energy can be extracted from a given module area. To increase the efficiency of amorphous silicon, many researchers in the US are working under the Thin Film PV Partnership program (DOE (US), 1999). These research teams are addressing a dozen issues surrounding the design and fabrication of multijunction amorphous silicon alloy cells. In addition, researchers are developing ways to process amorphous silicon material to improve its stabilized efficiency. The most promising approach to date is hot-wire deposition. The extremely hot $\left(2000^{\circ} \mathrm{C}\right)$ temperatures of the wire cause the feed gases to dissociate, and the active radicals are deposited at rates up to 10 times higher than those of the glowdischarge method used in industry today. Future work will investigate the viability of this alternative approach to replace existing processes in industry. By 2002, working with industry on device design and material deposition techniques, the US Department of Energy (DOE) aims to improve the stabilized efficiency of laboratory amorphous silicon devices. Moreover, it expects that research results will be quickly transferred to the production line because there is a mature manufacturing base for amorphous silicon (DOE (US), 1999).

Cadmium telluride is extensively explored because the techniques used to manufacture devices from this material including different evaporation techniques can be very low-cost. The technology also promises high efficiencies; small cells have reached nearly $16 \%$ at the laboratory but the commercial module efficiencies are still around 6\%. Improving module efficiencies requires a fundamental understanding of the properties of cadmium telluride which is yet limited. For example, as reported in (DOE (US) 1999), some modules have shown stable performance for 6 years outdoors, while others have shown significant decreases in efficiency in few days. Therefore, the mechanisms of this uncertain physical stability have to be characterized thoroughly. In addition, researchers often achieve high cell efficiencies using non-standard industry manufacturing techniques. Also, the high efficiencies of small-area cells are due in part to the deposition of very thin layers of cadmium sulfide. No one has learned how to deposit such a thin layer in a module-scale device, and a thicker layer reduces efficiency by about $25 \%$.

To meet challenges like these, many efforts should be gathered to realize the potential of cadmium telluride cells for high-efficiency power modules. Copper Indium Diselenide is also one of the potential PV materials, which gives high efficiency. It was in 1996 when researchers pushed the efficiency for devices based on this material to $17.7 \%$, the highest efficiency reported for any thin-film cell. It is the only stable thin-film material with several years of outdoor exposure that shows no deterioration in performance. But it is not yet commercial because significant further research is needed to understand the manufacturing processes. Fabricating high-quality films based on this material requires making a copper-rich layer and a copper-poor surface layer to form a junction with other alloys. Researchers studying this technology still have difficulty avoiding defects that prevent the formation of uniform layers. However, to achieve quality results, it is critical to use proper temperatures and correct timings during the different steps of the process.

The use of crystalline silicon is still prevalent. Although its absorption of sunlight is much less effectively (10-100 times) than other thin films, thin-layer crystalline silicon cells can be more efficient than those made of other thin-film materials. The issue is to construct properly the solar cell for maximum light trapping. The main advantage of using silicon is that its characteristics are well known and its technology as well. So far, researchers have succeeded to deposit relatively thick layers of crystalline silicon on low-cost substrates. However, future work will undoubtedly focus on thinning the material to less than 50 micrometers, while developing optimal substrate, light-trapping, and interconnection schemes.

On the other hand, crystalline silicon is likely to continue to dominate PV markets at least through the year 2000. With its relatively high efficiency and stability, competitive cost, and proven track record, it plays a dominant role in the whole PV market. Today's crystalline silicon devices are more efficient than ever before since laboratory cells made from single-crystal silicon have measured efficiencies as high as $24 \%$. Research on manufacturing improvements has pushed the efficiencies of multicrystalline devices to nearly $18 \%$ for laboratory cells and over $15 \%$ for prototype modules. 


\section{PHOTOVOLTAIC CELLS AND SYSTEMS}

Gallium Arsenide has also been used for many years for PV conversion with a measured singlejunction efficiency greater than $25 \%$ at one sun (no concentration) and about 28\% under sunlight concentration (MacMillan et al 1988, Maroto et al 1995). Multijunction cells based on gallium arsenide and related III-V alloys have even achieved conversion efficiencies greater than $30 \%$. The efficiency is expected to exceed 32\% after using these devices in concentrator systems (Tobin et al 1990, Olsen et al 1991). Due to its elevated cost, this technology is mostly restricted to military and space applications.

Further cost reductions in manufacturing technology are necessary to expand PV markets. Manufacturing costs depend on many factors of production, and a lot of research is being conducted to optimize several of them. One of these factors is the rate at which PV materials or devices are passed through the processes of material deposition, preparation, encapsulation, and connection to electrical components. The main objective is that the high-efficiency materials developed in the laboratory must ultimately be manufactured in quantity on the production line. Manufacturers and systems developers conduct research to integrate PV system components for optimal performance, reliability, and lifetime. They simplify systems and select the most durable components and they work to improve balance of systems components such as inverters, batteries, and control systems.

In addition to PV cells and modules, all PV systems must have other components that help to convert, deliver, and store electricity. Today, balance-of-system components represent about half the cost of a PV system, but they are responsible for $99 \%$ of system repair problems. Another major problem is that about $15 \%$ of the electricity generated by PV modules is lost during conversion and transmission through balanceof-system components. These include charge controllers, batteries, control systems, mounting hardware, tracking systems, wiring, and power-conditioning hardware such as inverters. Failures of inverters are the primary cause of photovoltaic system problems. A number of designs for mechanical or electronic balanceof-system components have been optimized for PV systems. Thus, their cost and performance should improve with improving designs. The cost of an entire PV system is also expected to decrease with rapid advances in power electronics performance.

Most of this fast-growing market for PV is targeted towards potential users who lack a reliable source of electricity. This potential market constitutes about $40 \%$ of the world's population whose needs often require small amounts of power for applications such as indoor lighting or pumping water. To take advantage of this huge market, efforts must be made to find ways to finance the purchase of PV systems and establish reliable installation and maintenance services.

\section{Conclusion}

The current and future trends in photovoltaic cells and systems have been reviewed in this paper.These included marketing and applications, system components and integration, manufacturing, and basic research. The cost of photovoltaic electricity is continuously falling down as the technology matures and many companies are now investing in research and pilot projects. This research has proven the value of photovoltaics in several applications. However, more work needs to be done to reduce the cost, and thus makes photovoltaic electricity competitive with other energy technologies. The cost of manufacturing equipment, in particular, must be reduced in order to keep up with the current trend of growth. As for the application of PV technology in Oman, it is well suited to the environment since it receives a high degree of solar radiation throughout the year. Various successful implementations for the PV technology are already in use. These include street lighting, powering of microwave repeaters and many others.

\section{References}

AL-ALAWI, S. M. S. and AL-HINAI, H. A., 1998, An ANN based approach for predicting global radiation in locations with no direct measurement instrumentation, Proceeding of the $6^{\text {th }}$ Arab International Solar Conf. Muscat, Oman, Published 
in Renewable Energy, 14, 1-4: 199-204.

ALBRIGHT, S. 1991. Final Report for PV Manufacturing Technology Phase I (Jan.-April 1991), NREL/TP-214-4569, DE91015032), Photon Energy Inc., Golden, CO.

AL-HINAI, H. A. and AL-ALAWI, S. M., Typical solar radiation data for Oman, Applied Energy, 52: Special issue Part I, Elsiever Applied Science.

AL-ISMAILY, H. A. and PROBERT, D 1998. Photovoltaic electricity prospects in Oman. Applied Energy, 59, 2-3, Elsevier Science, pp. 97-124, pp. 97-123.

AL-MALKI, A., AL-AMRI, M. and AL-JABRI H., 1998 Experimental study of using renewable energy in the rural areas of Oman, Proceeding of the $6^{\text {th }}$ Arab international solar Conf. Muscat, Oman, Published in Renewable Energy, 14, 1-4: 319-324.

ALSEMA, E.A. and VAN ENGELENBURG, B.C.W. 1992. Environmental risks of CdTe and CIS solar cell modules. Proceedings of the $11^{\text {th }}$ European Solar Energy Conference, Montreux, 12-16, 1992.

BARNETT, A M, KAZMERSKI, L. L., WETTLING, W. and YAMAGUCHI, M. 1999 'Foreword', IEEE Trans. on Electron Devices, 46(10), October 1999, p.1925.

BROWN, J. 1991. Final Report for PV Manufacturing Technology Phase I (Jan.-April 1991), NREL/TP-214-4478, DE91015027, Solar Cells Inc., Golden, CO.

CARICCHI, F., CRESCIMBINI, F., HONORATI, O., and SANTINI, E. 1993. Design and testing of a small-size windphotovoltaic system prototype. Proceedings of the European Community Wind Energy Conference, Germany, March 1993, pp. 740-743.

CHALIN, D. M., FULLER, C. S. and PEARSON, G. L. 1954. A New Silicon P-N Junction Photocell for Converting Solar Radiation into Electrical Power. J. Appl. Phys., 25: 676.

CHALMERS, B.J., SPOONER, E., HONORATI, O., SCHIAVONE, M., CRESCIMBINI, F., CARICCHI, F. and WU WEI 1996. Testing of a $10 \mathrm{~kW}$ prototype of combined Wind/PV isolated generating system. Proceedings of the 1996 European Union Wind Energy Conference, Goteborg, Sweden, May 1996, Paper No. 12.15, pp. 1-4.

CIZEK, T., SCHIETZELT, M., KAZMERSKI, L., HURD, J. and FERNELIUS, B. 1981. Proc. 15th IEEE PVSC, 1981, pp. 581-588.

CRESCIMBINI, F., CARICCHI, F., SOLERO, L., CHALMERS, B. J., SPOONER, E. and WU WEI 1996. Electric equipment for a combine Wind/PV isolated generator system. Proceedings of IEE Int. Conf. On Opportunities and Advances In International Power Generation, Durham, March 1996, Conf. Pub. No. 419, pp. 59-64.

DEPP (US) 1998. U.S. Department of Energy Photovoltaics Program.

DERENIAK, E. L. and GROWE, D. G. 1984. Optical Radiation Detectors. Wiley \& Sons, New York.

DOE (US) 1999. US Department of Energy, Internet URL: www.eren.doe.gov/pv/

DORVLO, A. S. S. and AMPRATWUM, D. B., 1998 " summary Climatic data for solar technology development in Oman", Proceeding of the $6^{\text {th }}$ Arab international solar Conf. Muscat, Oman, Published in Renewable Energy, 14, 1-4, pp- 255-262.

DOYLE, J., ROBERTSON, R., LIN, G. H., HE, M. Z. and GALLAGHER, A. 1988. Production of high quality amorphous silicon films by evaporative silane surface decomposition. J. Appl. Phys., 64(6): 3215-3223.

EDELMOSER, K. H., and HIMMELSTOSS, F. A. 1999. Analysis of a New High-Efficiency DC-to-AC Inverter. IEEE Trans. On Power Electronics, 14: 454-460.

EYER, A., SCHILLINGER, N., RAUBER, A. and GRABMAIER, J. 1989. Continuous processing of silicon sheet material by the SSP-Method. Proc. 9thEC PVSEC, Freiburg, Germany, 1989, pp. 17-18.

FALLER, F., SCHILLINGER, N., HURRLE, A. and SCHETTER, C. 1997. Improvement and Characterization of McSi Thin Film Solar Cells on Low-Cost SSP Ribbons. Proc. 14th EC PVSEC, Barcelona, Spain, 1997, pp. 784787.

GREEN M. A., EMERY K., BÜCHER K., KING D. L. and IGARI S. 1998. Solar Cell Efficiency Tables (Version 12), Progress in Photovoltaics: Research and Applications, Vol. 7, John Wiley \& Sons, Ltd.

GREEN, M. A., ZHAO, J., WANG, A., and WENHAM, S. R. 1999. Very High Efficiency Silicon Solar CellsScience and Technology. IEEE Trans. Electron Dev., 46(10): 1940-1947.

GUHA, S. 1997A. Materials aspects of amorphous silicon solar cells. Current Opinion Solid State Mater. Sci., 2/4: 425.

GUHA, S. and YANG, J. 1999. Science and Technology of Amorphous Silicon Alloy Photovoltaics. IEEE Trans. on Electron Devices, 46(10), October 1999, pp 2080-2085.

GUHA, S., YANG, J., Banerjee, A., Hoffman, K., Sugiyama, S., Call, J., Jones, S. J., Deng, X., Doehler, J., Izu, M. and Ovshinsky, H. C. 1997B. Triple-junction amorphous silicon alloy PV manufacturing plant of 5 MW annual capacity," in Conf. Rec., 26th IEEE PVSC, New York: IEEE, 1997, p. 607. 


\section{PHOTOVOLTAIC CELLS AND SYSTEMS}

HAHN, G., SPIEGEL, M., KELlER, S., BOUEKE, A., FATH, P., WILlEKE, G., BUCHER, E., HASSLER, C., HOFS, H. and THURM, S. 1997. Characterization of RGS Silicon Material and Solar Cells. Proc. 14th EC PVSEC, Barcelona, Spain, 1997, pp. 81-84.

HAHN, G., JOOSS, W., SPIEGEL, M., FATH, P., WILLEKE, G. and BUCHER, E. 1997. Improvement of mc-Si Solar Cells with Al-Gettering and Hydrogen Passivation. Proc. 26th IEEE PVSC, Anaheim, CA, 1997, pp. 75-78.

IZU, M. 1992. Final Report for PV Manufacturing Technology Phase I (Jan.-April 1991), REL/TP-214-4579, DE92001199, Energy Conversion Devices, Inc., Golden, CO.

JANOCH, R., WALLACE, R. and HANOKA, J. 1997. Commercialization of Silicon Sheet Via the String Crystal Growth Technique. Proc. 26th IEEE PVSC, Anaheim, CA, 1997, pp. 95-98.

JESTER, T. 1991. Final Report for PV Manufacturing Technology Phase I (Jan.-April 1991), NREL/TP-214-4481, DE92001153, Siemens Solar Industries, Golden, CO.

KALEJS, J., JASTRZEBSKI, L., LAGOWSKI, L., HENLEY, W., SCHIELEIN, D., BALSTER, S. and SCHRODER, D. 1994. Study of $\mathrm{Fe}$ and $\mathrm{Cr}$ pairing with B in polycrystalline silicon. Proc. 12th Eur. PVSEC, Amsterdam, The Netherlands, 1994, pp. 52-55.

KANEKO, K., KAWAMURA, R., MIZUMOTO, H. and MISAWA, T. 1997. Manufacturing of Polycrystalline Silicon Ingot by Electromagnetic Casting. Proc.11th Eur. PVSEC, 1997, pp. 1070-1073.

KAPUR, V.K. and BASOL, B. 1990. Key Issues and Cost Estimates for the Fabrication of CIS PV Modules by the Two-Stage Process. Proceedings of the 21st IEEE PV Specialists Conference, Orlando, 21-25 May, 1990. FL U.S.A., 1, pp. 467-470.

LAI, Z., and SMEDLEY, K. M. 1995. A low distortion switching audio power amplifier. Proceedings of 26th Annu. IEEE Power Electronics Specialists Conf. PESC'95, 1995, vol. 1, pp. 174-180.

LUFT, W. and VON ROEDERN, B. 1994. Considerations for Light Soaking of Amorphous Silicon PV Modules. Proceedings of the First World Energy Conference on PV Energy Conversion, 1994.

MACKINTOSH, B., SUREK, T., KALEJS, J., SACHS, E., NAGY, S., and WALD, F. 1978. Multiple silicon ribbon growth by EFG. Proc. 13th IEEE PVSC, New York, 1978, pp. 350-357.

MACMILlAN, H. F., HAMAKER, H.C., KAMINAR, N. R., KURYLA, M. S., RISTOW, M. L., LIU, D. D., VIRSHUP, G. F. and GEE, J. M. 1988. 28\% efficient GaAs concentrator solar cells. Proceedings of the 20th IEEE Photov. Spec. Conf., Las Vegas, NV, 1988, pp. 462-468.

MAKINO, M., TANAKA, K., MACKAWA, M., SUZUKI, R., OSUMI, M., and TSUKAMOTO, K. 1995. Digital control method for a photo voltaic power system. Proceedings of Int. Power Electronics Conf. IPEC'95, Apr. 1995, 1, pp. 197-202.

MANTOVANELLI, P., and BARBI, I. 1995. A new current-fed isolated PWM dc-dc converter. Proceedings of IEEE Applied Power Electronics Conf., Mar. 1995, 2, pp. 290-296.

MAROTO, J. C., MARTI, A., ALGORA, C. and ARAUJO, G. L. 1995. 1300 suns GaAs concentrator solar cell with efficiency over 23\%. Proceedings of the $13^{\text {th }}$ European Photov. Solar Energy Conf., Nice, France, 1995, pp. 343-348.

MATSUMURA, H. 1986. Catalytic Chemical Vapor Deposition (CTL-CVD) Method Producing Higher Quality Hydrogenated Amorphous Silicon., Jpn. J. Appl. Phys., 25(2): L949-L951.

MAURITS, J. 1998. Polycrystalline silicon-World demand and supply," in Proc. 8th Workshop Crystalline Silicon Solar Cells Materials and Processes, Aug. 17-18, 1998, pp. 10-17.

MEYERS, P.V. 1990. Polycrystalline Cadmium Telluride n-i-p Solar Cells. SERI Subcontract Report, ZL-7-06031-2, Final Report, Solar Energy Research Institute, Golden, CO.

MIDYA, P., KREIN, P. T., TURNBULL, R. J., REPPA, P., and KIMBALL, J. 1996. Dynamic maximum power point tracker for photovoltaic applications. Proceeding of IEEE Power Electronics Specialists Conf. PESC'96, June 1996, 2, pp. 1710-1716.

MOSKOWITZ P.D. and ZWEIBEL, K. (Editors) 1992. Recycling of Cadmium and Selenium from PV Modules and Manufacturing Wastes. A Workshop Report, BNL 47787, Brookhaven National Laboratory, Golden CO.

MOSKOWITZ, P.D. and FTHENAKIS, V.M. 1990. Toxic materials released from PV Modules During Fires: Health Risks. Solar Cells, 29: 63-71.

MOSKOWITZ, P.D., HAMILTON, L. D., MORRIS, S. C., NOVAK, K. M. and ROWE, M. D. 1990B. Photovoltaic Energy Technologies. Health and Environmental Effects Document. BNL-51284, Brookhaven National Laboratory, Upton, New York.

MOSKOWITZ, P.D., FTHENAKIS, V.M. and ZWEIBEL, K. 1990A. 'Health and safety issues related to the production, use, and disposal of Cd-based PV modules. Proceedings of the 21st IEEE PV Specialists Conference, Orlando, 21-25 May 1990, FL U.S.A. 
MOSKOWITZ, P.D., FTHENAKIS, V.M., HAMILTON, L.D. and LEE, J.C. 1987. Public health issues in PV energy systems: an overview of concerns. Sol. Cells, 19: 287-299.

MOSKOWITZ, P.D., ZWEIBEL, K. and FTHENAKIS, V.M. 1990C. Health, Safety, and Environmental Issues Relating to Cadmium Usage in PV Energy Systems. SERI/TR-211-3621, DE90000310, NREL, Golden, CO, 1990.

MOSS, T. S. (Editor) 1981. Handbook on Semiconductors. 4, edited by C. HILSUM, North Holland Pub. Comp..

MUNZER, K. A., HOLDERMANN, K. T., SCHLOSSER, R. E., and STERK, S. 1998. Improvements and benefits of thin crystalline solar cells. Conf. Rec. 2nd World Conf. PVSEC, Vienna, Austria, 1998, pp. 1214-1219.

NIJS, J. F., SZlUfCIK, J., POORTMANS, J., SIVOTHTHAMAN, S., and MERTENS, R. P.1999. Advanced Manufacturing Concepts for Crystalline Silicon Solar Cells. IEEE Trans. Electron Dev., 46(10): 1948-1969.

NREL (Editor) 1996. Report of the National Renewable Energy Laboratory (NREL) for the U S Dept. of Energy, May 1996, DOE/GO-10095-241, DE96000486.

OLIVEIRA, C., and MAKSIMOVIC, D. 1996. Zero-current-transition converters for high-power-factor ac/dc applications. Proceedings of IEEE Applied Power Electronics Conf., March 1996, 1, pp. 159-165.

OLSEN, L. C., HUBER, D. A., DUNHAM, G. and ADDIS, F. W. 1991. High efficiency monochromatic GaAs solar cells. Proceedings of the 22nd IEEE Photov. Spec. Conf., Las Vegas, NV, 1991, pp. 419-424.

ORE (US) 1989, Meridien Corporation, Energy System Emissions and Material Requirements, prepared by US Department of Energy, Office of Renewable Energy, Washington, DC.

PIERRET, R. F., 1996. Semiconductor Device Fundamentals. Addison Wesley, pp. 17-18.

RUSSELL, T.W.F., BARON, B. N. and ROCHELEAU, R. E. 1984. Economics of Processing Thin-Film Solar Cells. J. Vac. Sci. Technol., B2(4): 840-844.

SAN MARTIN, R.L. 1989. Environmental Emissions from Energy Technology Systems: The Total Fuel Cycle. Publication of the US Department of Energy, Washington, DC.

SANA, P., ROHATGI, A., KALEJS, J. and BELL, R. 1993. The Effect of Aluminum Treatment and Forming Gas Anneal on EFG Silicon Solar Cells. Proc. 23rd IEEE PVSC, Louisville, KY, 1993, pp. 111-114.

SAYIGH, A. A. M. (Editor), 1998. Bringing Solar energy into the daylight. Proceedings of the $6^{\text {th }}$ Arab International Solar Energy Conference. Muscat 29 Mar. to 1 Apr. 1998, Oman.

SCHMIDT, J., ABERLE, A. AND R. HEZEL 1997. Investigation of carrier lifetime instabilities in Cz-grown silicon. Proc. 26th IEEE PVSC, 1997, pp.13-18.

SCHROPP, R. E. I. and RATH, J.K. 1999. Novel profile thin-film polycrystalline silicon solar cells on stainless steel substrates. IEEE Trans. Electron Dev., 46( 10):.2069-2071.

SOLERO, L., CARICCHI, F., CRESCIMBINI, F., HONORATI, O., and MEZZETTI, F. 1996. Performance of a 10 $\mathrm{kW}$ power electric interface for combined wind/PV isolated generating systems. Proceedings of IEEE Power Electronics Specialists Conf. PESC'96, June 1996, 2, pp. 1027-1032.

STANBERY, B.J. 1991. Final Report for PV Manufacturing Technology Phase I (Jan.-April 1991), NREL/TP-2144606, DE92001176, Boeing Aerospace \&; Electronics, Golden, CO.

STEINBACH I. and HOFS, H. 1997. Microstructural analysis of the crystallization of silicon ribbons produced by the RGS process. Proc. 26th IEEE PVSC, Anaheim, CA, 1997, pp. 91-93.

STONE, J.L., WITT, E., MCCONNELL, R. and FLAIM, T. 1984. Proc. 17th IEEE PV Specialists Conference, pp. 178.

STONE J. L. 1993. Photovoltaics: Unlimited Electrical Energy From the Sun. Physics Today.

SZE, S. M. 1985. Semiconductor Devices: Physics and Technology. John Wiley \& Sons, New York.

SZE, S. M. 1999. Physics of Semiconductor Devices $\left(2^{\text {nd }}\right.$ Edition). Wiley \& Sons, New York.

TAYLOR, A., STORMONT, R., CHAO, C. and HENDERSON, E. 1981. Large area silicon sheet via EFG tube growth. Proc. 15th IEEE PVSC, 1981, pp. 589-594.

TOBIN, S. P., VERNON, S. M., WOJTCZUK, S. J., BAJGAR, C., SANFACON, M. M. and DIXON, T. M. 1990. Advances in high-efficiency GaAs solar cells. Prococeedings of the 21st IEEE Photov. Spec. Conf., Kissimimee, FL, 1990, pp. 158-162.

TOLLEY, W.K. and PALMER, G.R. 1991. Recovering Cadmium and Tellurium from CdTe Manufacturing Scrap. Proceedings of the 1991 AIME Annual Meeting, New Orleans, LA, February 1991, Bureau of Mines, Salt Lake City, Utah.

VILLERS, T. and SMEKENS, G. R. 1995. Monoches II-Final Rep. JOU2-CT92-0140.

WAGNER, S. and CARLSON, D. E. 1991. Amorphous silicon solar cells. Proceedings of the $10^{\text {th }}$ E.C. Photovoltaic Solar Energy Conference, Kluwer Academic, Dordrecht, pp. 1179-1183. 


\section{PHOTOVOLTAIC CELLS AND SYSTEMS}

WALlACE, R., HANOKA, J., NARASIMHA, S., KAMRA, S. and ROHATGI, A. 1997. Thin Silicon String Ribbon for High Efficiency Polycrystalline Solar Cells. Proc. 26th IEEE PVSC, Anaheim, CA, 1997, pp. 95-98.

WATANABE, H., SHIRASAWA, K., MASURI, K., OKADA, K., TAKAYAMA, M., FUKUI, K. and YAMASHITA, H. 1990. Technical progress on large area multicrystalline silicon solar cells and its applications. Optoelectronics Device Technol., 5: 223-238.

WIESMAN, H., GHOSH, A. K., MCMAHON, T. and STRONGIN, M. 1979. A-Si: H Produced by High Temperature Thermal Decomposition of Silane. J. Appl. Phys., 50(5): 3752-3754.

WOHLGEMUTH, J.H., WHITEHAUSE, D., WIEDEMAN, S., CATALANO, A.W. and OSWALD, R. 1991. Final Report for PV Manufacturing Technology Phase I (Jan.- April 1991), NREL/TP-214-4483, DE92001166, Solarex Corporation, Golden, CO.

YAMAMOTO, K. 1999. Very thin crystalline solar cells on glass substrate at low temperature. IEEE Trans. Electron Dev., 46( 10): 2041-2047.

ZWEIBEL, K. and CHU, T.L. 1993. Cadmium Telluride Photovoltaics. In Advances in Solar Energy, 8, ed. by M. Prince, American Solar Energy Society, Boulder, CO.

ZWEIBEL, K. and MITCHELL, R. 1990. CuInSe 2 and CdTe Scale-up for Manufacturing. In Advances in Solar Energy, ed. by K. Boer, Plenum Press, New York.

Received 31 January 2000

Accepted 13 June 2000 